Journal of Science

and Engineering

Full Paper

\title{
ANALISIS KOMPARASI KLASIFIKASI TUTUPAN \\ Vegetasi Melalui Citra Drone dan Satelit \\ Dalam MENENTUKan TingKat KeBERHaSILAN \\ REKLAMASI LAHAN BEKAS TAMBANG
}

\author{
Article History \\ Received \\ 4 okt 2020 \\ Accepted \\ 5 Mei 2021
}

Endy Thorino Juanda ${ }^{\mathrm{a}}$

aKementerian Energi dan Sumber Daya Mineral, Jakarta Indonesia

*Corresponding author endythorino@outlook.com

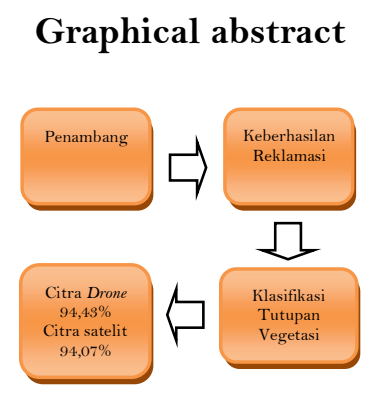

\begin{abstract}
The final stage of mining activities is reclamation that has the purpose to recover environment quality and ecosystem so that it has suitability with pre-disturbed land use. One of the criteria for reclamation of revegetation on ex-mines if the canopy cover has reached $\geq 80 \%$. The purpose of this study is to perform a comparative analysis of vegetation cover classification methods with drone data and Sentinel-2 satellite imagery in a vegetation state from a reclaimed area. Base on the calculation using drone imagery (acquisition On July $9^{\text {th }}, 2020$ ) shows $94.43 \%$ of the vegetation coverage compared by Sentinel-2 satellite imagery (acquisition On June $6^{\text {th }}, 2020$ ) data processing shows $94.07 \%$ of the vegetation coverage. It can be concluded that using both datasets results in no significant difference in vegetation cover (less than $1 \%$ ).
\end{abstract}

Keywords: Reclamation, Revegetation, Mining, vegetation Cover

\begin{abstract}
Abstrak
Tahapan akhir dari suatu kegiatan usaha pertambangan adalah reklamasi yang bertujuan untuk memperbaiki kualitas lingkungan dan ekosistem sehingga dapat berfungsi kembali sesuai dengan peruntukkannya. Salah satu kriteria keberhasilan reklamasi revegetasi lahan bekas tambang adalah apabila tutupan tajuk telah mencapai $\geq 80 \%$. Tujuan dalam penelitian ini adalah untuk mengalisis komparasi penggunaan metode Vegetation Cover Cassification (Klasifikasi Tutupan Vegetasi) dengan menggunakan data drone dan citra satelit Sentinel-2 dalam menentukan persentase vegetasi dari suatu area reklamasi. Dari perhitungan dengan menggunakan data citra drone yang akuisisi pada 9 Juni 2020 didapat persentase vegetasi 94,43\% sedangkan dari pengolahan data citra satelit Sentinel-2 yang di akuisisi tanggal 6 Juni 2020 di dapat persentase vegetasi 94,07\%. Dapat disimpulkan bawah penggunaan kedua dataset ini menghasilkan perbedaan persentase tutupan vegetasi yang tidak signifikan $(<1 \%)$.
\end{abstract}

Kata kunci: Reklamasi, Revegetasi, Penambangan, Tutupan vegetasi

(C) 2021 Penerbit Fakultas Teknik Unkhair. All rights reserved

\subsection{PENDAHULUAN}

Reklamasi merupakan tahap akhir suatu kegiatan usaha pertambangan [1] yang bertujuan untuk menata, memulihkan, dan memperbaiki kualitas lingkungan dan ekosistem agar dapat berfungsi kembali sesuai dengan peruntukkannya [2]. Reklamasi dapat dilakukan sesegera mungkin tanpa harus menunggu keseluruhan kegiatan usaha pertambangan berakhir.

Remote sensing merupakan sumber data yang sangat penting dalam mengestimasi tutupan vegetasi untuk area yang sangat luas [3], indeks vegetasi berbasiskan satelit telah banyak digunakan dalam berbagai penelitian 
untuk mengestimasi tutupan vegetasi $[4][5][6]$, indeks vegetasi ini mengukur radiometri spasial dan temporal aktivitas fotosintesis vegetasi yang berkaitan dengan variabel biofisik kanopi seperti leaf area indeks (LAI), tutupan vegetasi, biomassa, dan lainnya. Normalized Difference Vegetation Index (NDVI) [7], Ratio Vegetation Index (yang juga dikenal sebagai Simple Ratio) [8], Green Normalized Difference Vegetation Index [9] dan Green Difference Vegetation Index [10] adalah indeks vegetasi yang umumnya digunakan untuk mengukur kerapatan tanaman dan karakteristik biologi tutupan tajuk [11].

Tutupan vegetasi merupakan indikator yang paling sensitif dalam degradasi lahan [12] dan mempunyai efek yang sangat penting dalam pertukaran energi di permukaan bumi. Penentuan persentase tutupan vegetasi merupakan metode yang paling cocok dalam mengidentifikasi degradasi lahan [3].

Reklamasi dinyatakan berhasil bila telah memenuhi kriteria keberhasilan sesuai dengan yang diatur dalam Lampiran V Keputusan Menteri Energi dan Sumber Daya Mineral Nomor 1827.K/30/MEM/2018. Tutupan tajuk adalah salah satu parameter penting dalam keberhasilan reklamasi lahan bekas tambang [2]. Standar keberhasilan tutupan tajuk apabila telah mencapai $\geq 80 \%$ [2]. Berbagai metode telah digunakan dalam penelitian terdahulu untuk mengestimasi tutupan tajuk diantaranya line-poin intercept, grid-poin intercept, ocular estimate [13], digital photography [14], analisis indeks vegetasi [15]. Analisis tutupan tajuk dengan menggunakan data citra satelit telah banyak dilakukan namun untuk analisis tutupan tajuk melalui pengolahan data foto udara drone dengan metode vegetation cover classification (klasifikasi tutupan vegetasi) untuk mengevaluasi keberhasilan reklamasi belum banyak dilakukan. Dalam penelitian ini akan dilakukan studi komparasi untuk menentukan deviasi perhitungan tutupan tajuk dari kedua dateset tersebut.

\subsection{METODE PENELITIAN}

Penelitian ini dilakukan dengan metode kuantitatif yang berlokasi di Kabupaten Tanah Bumbu, Provinsi Kalimantan Selatan pada area lahan bekas penambangan batubara yang sudah lakukan reklamasi dengan koordinat $115^{\circ} 36^{\prime} 23^{\prime \prime} \mathrm{E} 3^{\circ} 23^{\prime} 36^{\prime \prime} \mathrm{S}$. Metode analisis yang digunakan yaitu analisis data foto citra drone yang di akuisisi pada 9 Juli 2020 dengan resolusi 0,69 meter dan citra satelit Sentinel-2 yang diakuisisi pada 6 Juni 2020 dengan resolusi 10 meter.

Prosedur kerja dalam penelitian ini terdiri dari studi literatur, analisis data foto udara drone, analisis citra satelit Sentinel-2, foto geotagging sampling kualitas tanaman. Studi literatur yaitu berasal dari laporan, makalah dan jurnal. Analisis data foto drone dilakukan dengan pengamatan visual dan pengolahan data dengan metode vegetation cover classification (klasifikasi tutup vegetasi) menggunakan software ArcGIS Pro 2.6 untuk menentukan persentase vegetasi.

\subsection{HASIL DAN PEMBAHASAN}

\subsection{Reklamasi Revegetasi}

Kegiatan reklamasi dilakukan pada tahun 2014 dengan luas area 1,71 ha yang terdiri dari kegiatan penatagunaan lahan, revegetasi dan penyelesaian akhir. Kegiatan penatagunaan lahan terdiri atas penataan lahan, penebaran zona pengakaran, pengendalian erosi dan sedimentasi. Revegetasi dilakukan dengan penanaman tanaman penutup tanah (legume cover crop) terlebih dahulu yaitu centrocema menguides, Centrocema pubescens, Peuraira javanica dan Mucuma prurines kemudian dilanjutkan dengan penanaman pionir spesies lokal yaitu tanaman Sungkai (Peronem canescens), pionir jenis eksotik yaitu tanaman Johar (Senna siamea) dengan jarak tanam 4x4 meter atau 625 tanaman/ha dan tanaman sisipan buah-buahan rambutan (Nephelium spp), durian (Durio zibethinus), cempedak (Artocaprus integer), Mangga (Mangifera spp) [16].

\subsection{Analisis Foto Citra Drone, Foto Geotagging dan Citra Satelit Sentinel-2}




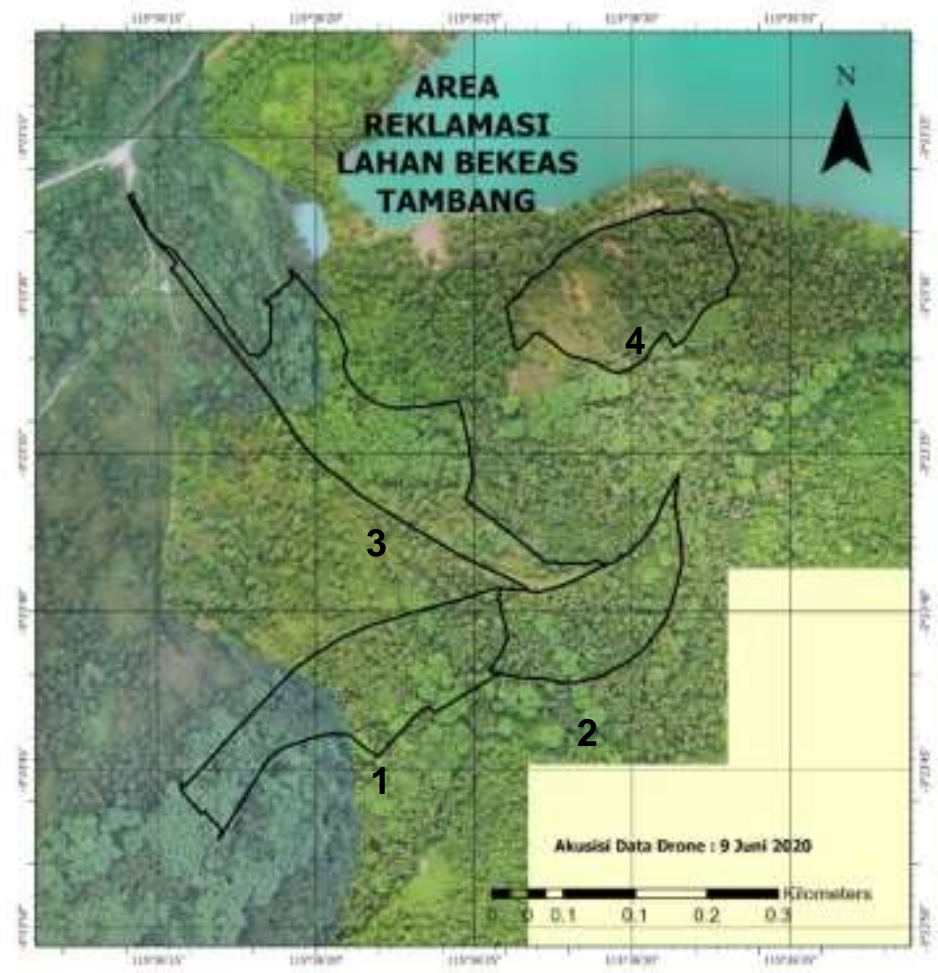

Gambar 1. Foto Citra Udara Drone Area Reklamasi [16]

Dari foto citra udara drone pada Gambar 1 menunjukkan area reklamasi tersebut sudah sebagian besar telah tertutupi vegetasi namun terdapat sebagian kecil area yang pertumbuhan vegetasi masih kurang baik (Gambar 1 area 4$)$.

Pengambilan foto geotagging (Tabel 1 dan Gambar 2) dilakukan untuk memastikan bahwa area tersebut merupakan area yang sudah ditanamani tanaman pionir. Dari foto geotagging menunjukkan bahwa area reklamasi tersebut sebagian besar merupakan area tanaman dengan pertumbuhan baik dan telah terbentuk tajuk sehingga proses analisis vegetation cover classification (klasifikasi tutupan vegetasi) untuk menghitung persentase tutup vegetasi dapat dilakukan.

Tabel 1. Foto Geotagging Tanaman Reklamasi [16]

NO KOORDINAT FOTO

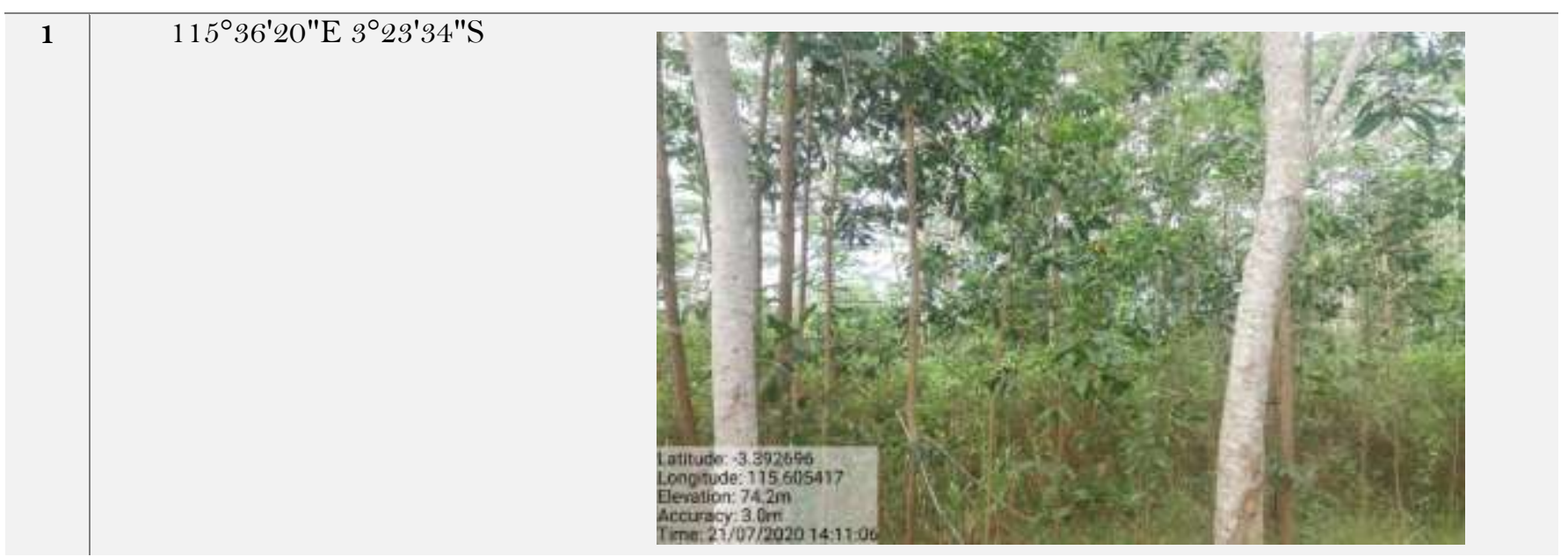




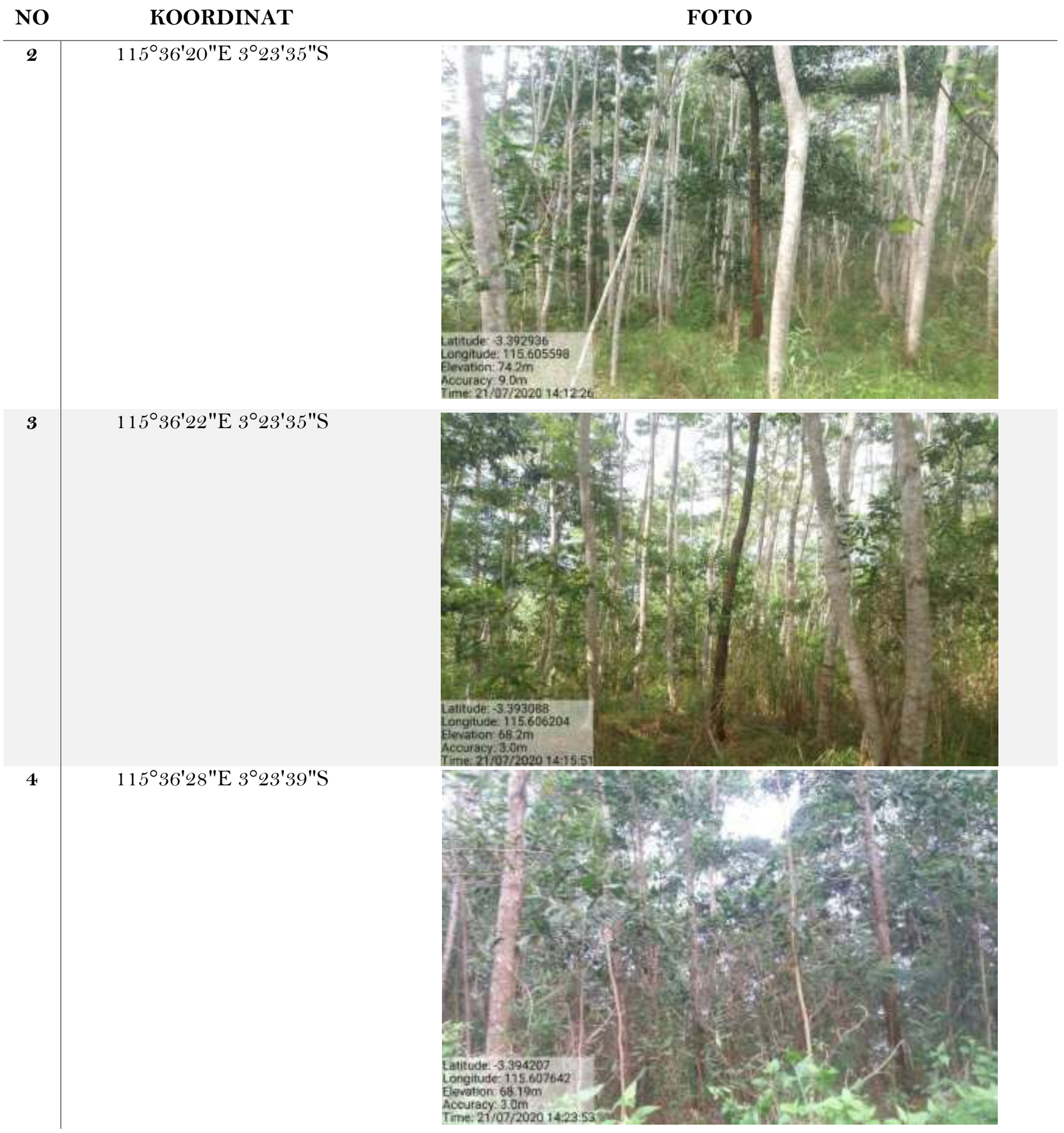




\section{NO KOORDINAT}

FOTO
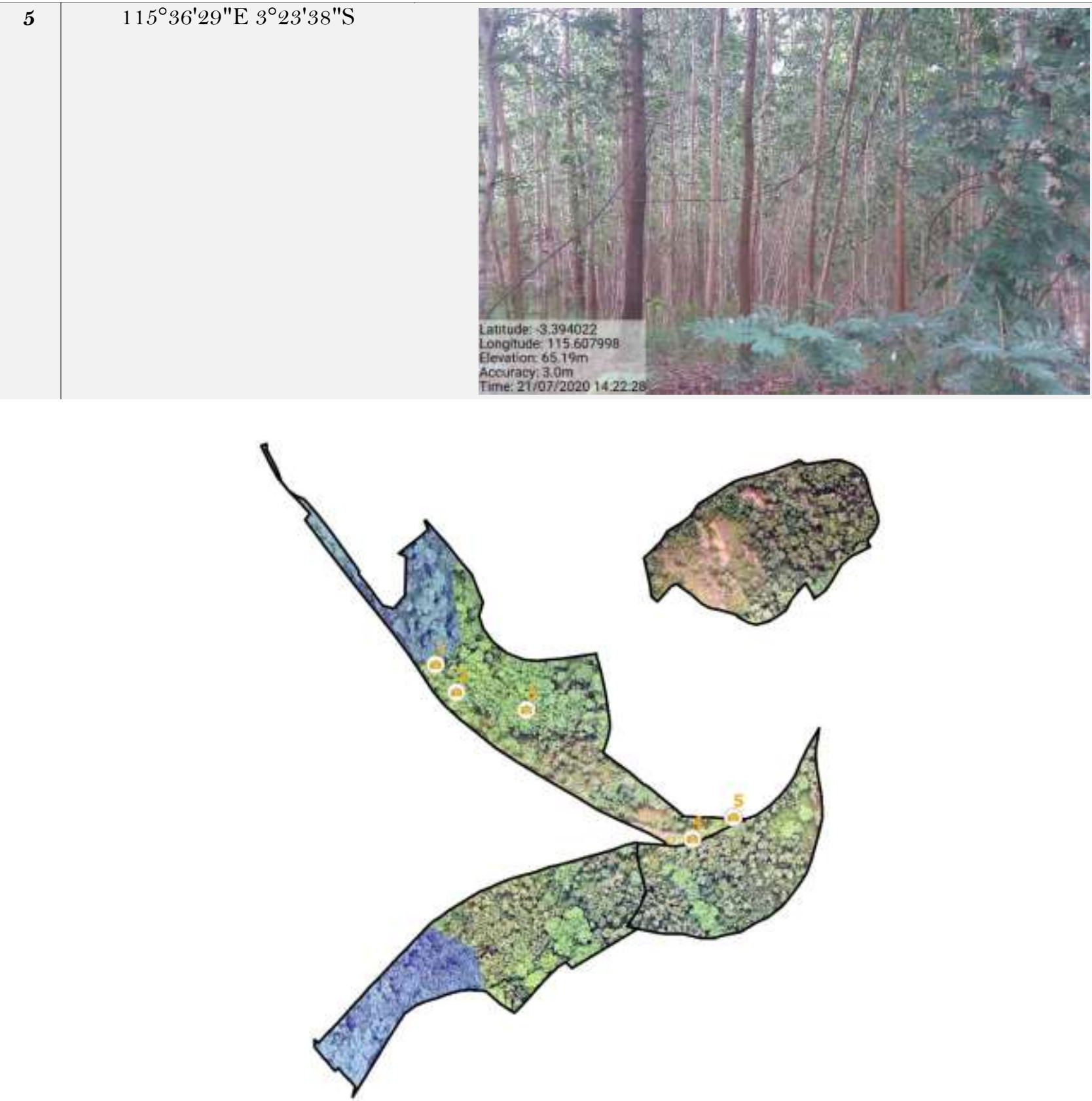

Gambar 2. Titik Koordinat Pengambilan Foto Geotagging Tanaman Reklamasi [16]

Analisis vegetation cover classification (klasifikasi tutupan vegetasi) dilakukan dengan metode unsupervisied dengan mengambil 50 training sample untuk mengklasifikasi area vegetasi dan non-vegetasi sehingga di dapatkan area luasan dan persentase area yang tertutupi vegetasi dan non-vegetasi. 


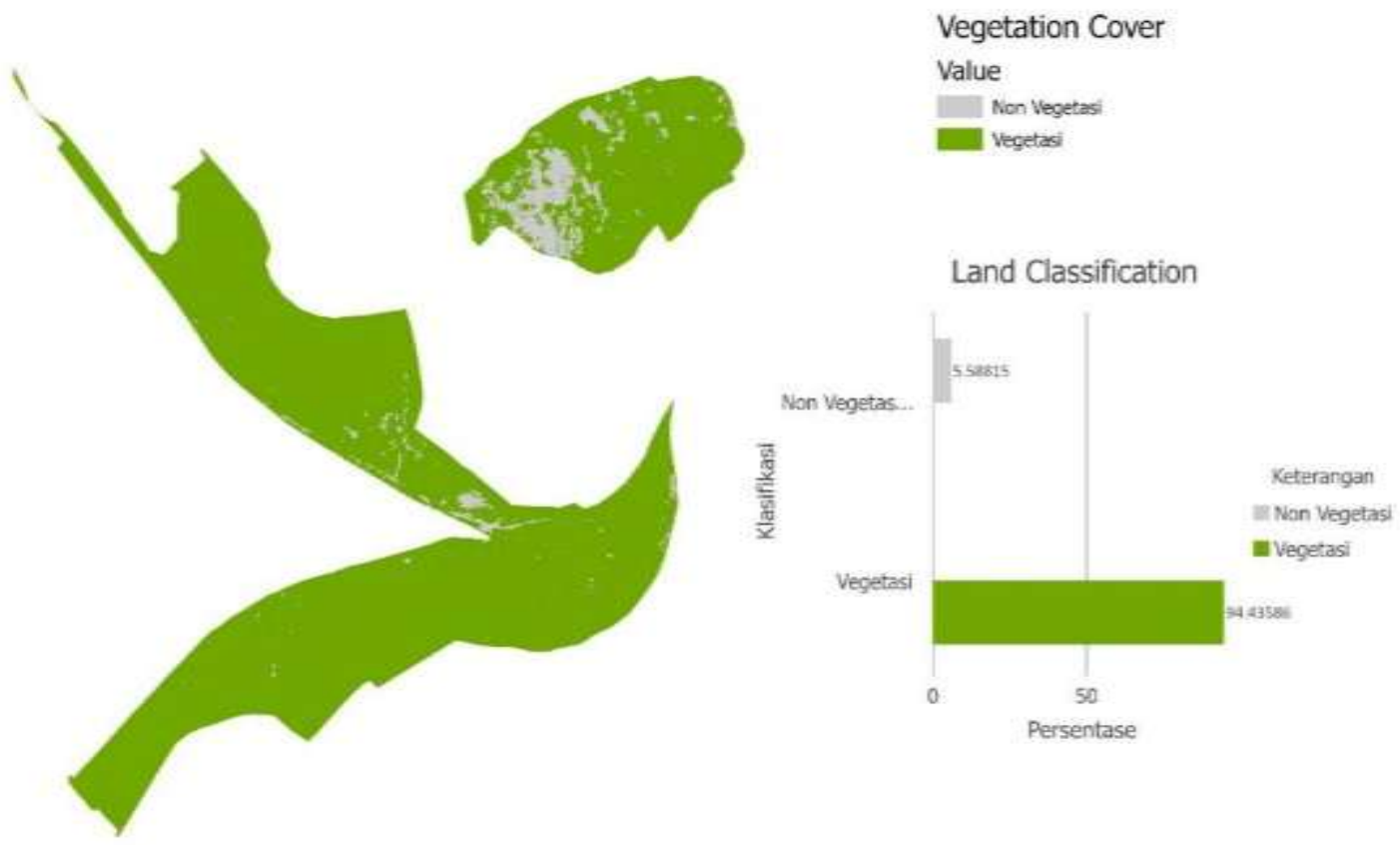

Gambar 3. Vegetation Cover Classifications (Klasifikasi Tutupan Vegetasi) Area Reklamasi

Dari analisis vegetation classification (klasifikasi tutupan vegetasi) pada Gambar 3 menunjukkan bahwa persentase tutupan tajuk mencapai 94,43\% sedangkan area yang belum tertutupi vegetasi (non-vegetasi) 5,58\%.

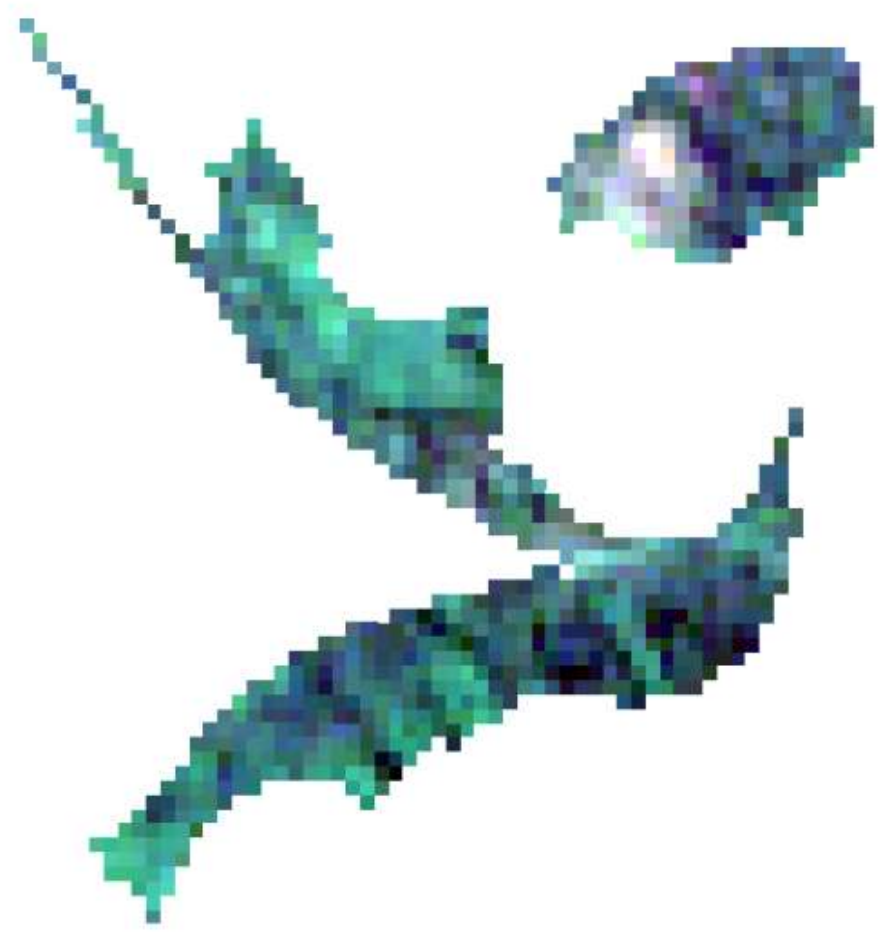

Gambar 4. Clip Raster Citra Satelit Sentinel-2 


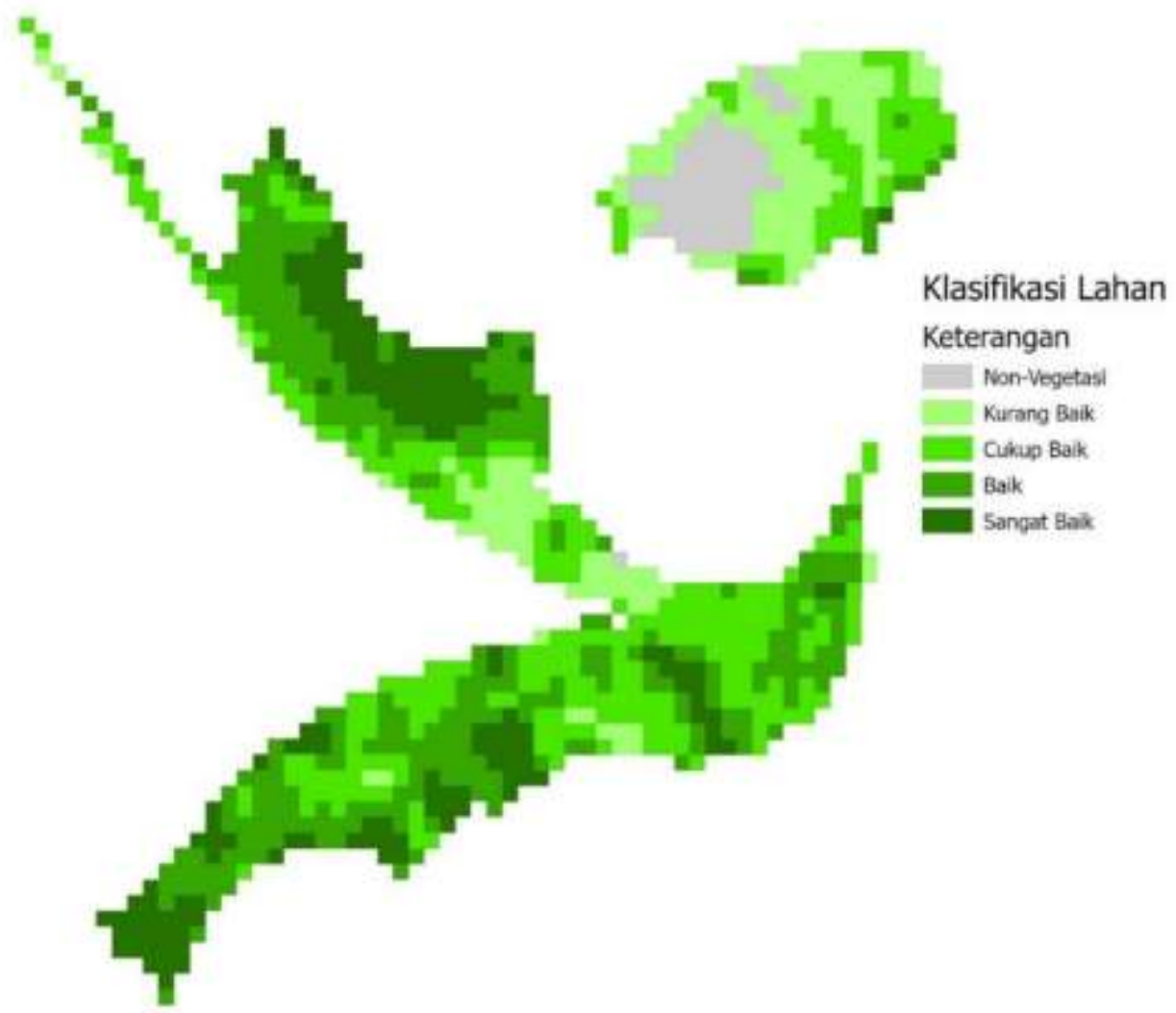

Gambar 5. Vegetation Cover Classifications (Klasifikasi Tutupan Vegetasi) Area Reklamasi dari Citra Satelit Sentinel-2

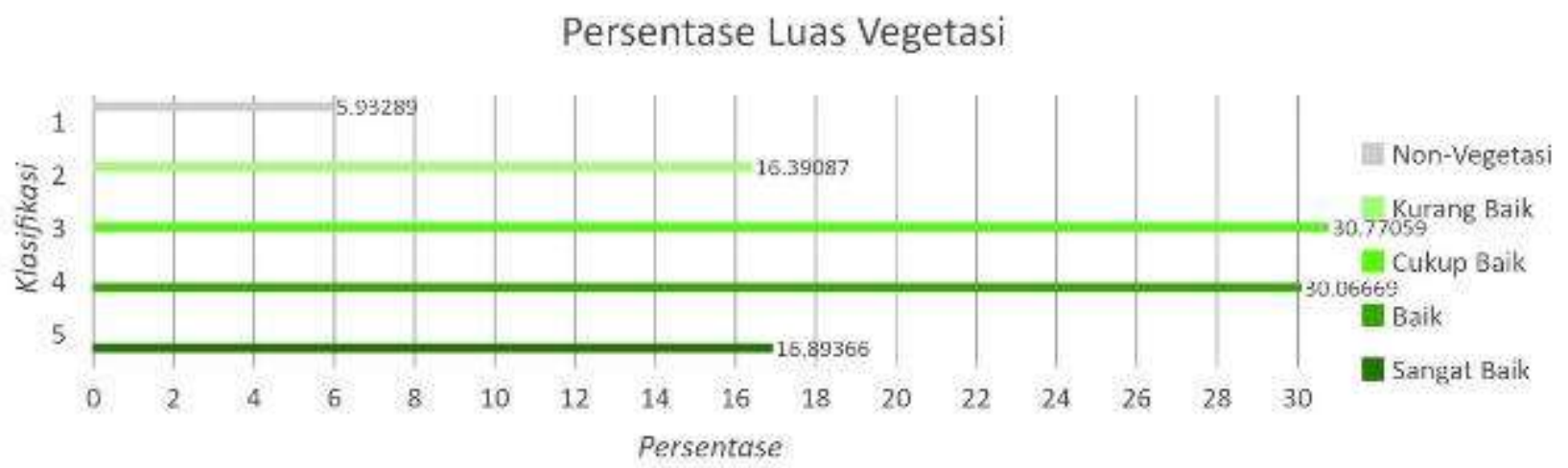

Gambar 6. Grafik Persentase Luas Dengan Menggunakan Perhitungan Vegetation Cover Classifications (Klasifikasi Tutupan Vegetasi) Citra Satelit

Analis terhadap area reklamasi dilakukan dengan menggunakan data citra satelit Sentinel-2 dengan resolusi $10 \mathrm{~m}$ yang di akuisisi pada tanggal 6 Juni 2020. Analisis ini dilakukan dengan menggunakan perhitungan indeks vegetasi Ratio Vegetation Index / Simple Ratio (SR) [8] yang memiliki akurasi yang lebih baik bila dibandingkan dengan Normalized Difference Vegetation Index [17].

$$
S R=\frac{\text { Band NIR }}{\text { Band Red }}
$$

NIR = Near Infra Red (Infra Merah Dekat) 
Red = Infra merah

Dari Gambar 5 persentase luasan area vegetasi mencapai 94,07\% atau 0.25\% lebih rendah bila dibandingkan klasifikasi lahan dengan menggunakan data drone. Perbedaan ini disebabkan oleh pengambilan data pada bulan yang berbeda namun perbedaan ini masih di bawah $1 \%$ sehingga dapat disimpulkan analisis klasifikasi lahan untuk menghitung tutup tajuk terhadap area reklamasi dengan menggunakan foto udara drone dan citra satelit mempunyai tingkat akurasi yang hampir sama. Perhitungan persentase tutupan tajuk dengan menggunakan citra satelit Sentinel-2 dapat diklasifikasikan sesuai dengan kualitas tanamannya namun untuk perhitungan dengan data drone sangat tergantung pada ketelitian dalam menentukan training sample.

Tabel 2. Perbandingan Vegetation Cover Classification (Klasifikasi Tutupan Vegetasi) Menggunakan Data Drone dan Cita Satelit Sentinel-2

\begin{tabular}{|c|c|c|c|c|}
\hline DATA & METODE & PENGOLAHAN & KELEMAHAN & KEUNGGULAN \\
\hline DRONE & $\begin{array}{l}\text { Klasifikasi } \\
\text { Nilai Pixel }\end{array}$ & $\begin{array}{l}\text { Penentuan training } \\
\text { sampel vegetasi dan non- } \\
\text { vegetasi }\end{array}$ & $\begin{array}{l}\text { - Metode yang digunakan } \\
\text { masih memerlukan } \\
\text { intervensi manusia } \\
\text { sehingga perlu ketelitian } \\
\text { dalam menentukan training } \\
\text { sampel sebelum di proses } \\
\text { oleh mesin (machine } \\
\text { learning). } \\
\text { - Membutuhkan waktu yang } \\
\text { lama terutama dalam } \\
\text { menentukan training } \\
\text { sampel }\end{array}$ & $\begin{array}{l}\text { - Resolusi citra } \\
\text { lebih tinggi bila } \\
\text { dibandingkan } \\
\text { dengan data citra } \\
\text { satelit } \\
\text { - Hasil yang } \\
\text { didapat tidak } \\
\text { berbeda jauh } \\
\text { dengan } \\
\text { pengolahan data } \\
\text { citra satelit }\end{array}$ \\
\hline $\begin{array}{l}\text { CITRA } \\
\text { SATELIT }\end{array}$ & $\begin{array}{l}\text { Klasifikasi } \\
\text { Nilai Pixel }\end{array}$ & $\begin{array}{l}\text { Penentuan vegetasi dan } \\
\text { non-vegetasi berdasarkan } \\
\text { nilai indeks vegetasi }\end{array}$ & $\begin{array}{l}\text { - Metode yang digunakan } \\
\text { adalah dengan melakukan } \\
\text { perhitungan nilai indeks } \\
\text { vegetasi (dalam penelitian } \\
\text { ini indeks vegetasi yang } \\
\text { digunakan adalah Ratio } \\
\text { Vegetation Index / Simple } \\
\text { Ratio (SR) [8] } \\
\text { - Sangat tergantung } \\
\text { ketersediaan data citra } \\
\text { (tidak tersedia setiap } \\
\text { waktu) dan dipengaruhi } \\
\text { atmosfer. }\end{array}$ & $\begin{array}{l}\text { - Proses lebih cepat } \\
\text { - Hasil yang } \\
\text { didapat tidak } \\
\text { berbeda jauh } \\
\text { dengan } \\
\text { pengolahan data } \\
\text { drone }\end{array}$ \\
\hline
\end{tabular}

\subsection{KESIMPULAN}

Analisis Vegetation Cover Classification (Klasifikasi Tutupan Vegetasi) untuk menghitung tutup vegetasi terhadap area reklamasi dengan menggunakan foto udara drone dan analisis citra satelit dengan menggunakan Ratio Vegetation Index / Simple Ratio (SR) menghasilkan perbedaan persentase tutupan vegetasi yang tidak signifikan $(<1 \%)$. Penggunaan data citra satelit dapat gunakan dalam menghitung persentase tutupan vegetasi area reklamasi bila data drone tidak tersedia begitupun sebaliknya, data drone dapat digunakan bila data citra satelit dipengaruhi atmosfer (misal tertutup awan).

\section{Ucapan Terima Kasih}

Ucapan terima kasih disampaikan kepada semua pihak khususnya PT X yang telah berperan dalam membantu dalam penelitian ini. 


\section{Daftar Pustaka}

[1] L. H. Howard and M. M. Jan, Introduction to mining, Second. Hoboken, New Jersey: John Wiley \& Sons, Inc., 2002.

[2] Menteri Energi dan Sumber Daya Mineral, Keputusan Menteri Energi dan Sumber Daya Mineral nomor $1827 \mathrm{~K} / 30 / \mathrm{MEM} / 2018$ tentang pedoman pelaksanaan kaidah teknik pertambangan yang baik. 2018.

[3] J. Xiao and A. Moody, "A comparison of methods for estimating fractional green vegetation cover within a desert-to-upland transition zone in central New Mexico , USA," Remote Sens. Environ., vol. 98, pp. 237$250,2005$.

[4] F. J. Garcı and J. Melia, “A generalized soil-adjusted vegetation index,” Remote Sens. Environ., vol. 82, pp. 303-310, 2002.

[5] Z. Jiang, A. R. Huete, K. Didan, and T. Miura, "Remote Sensing of Environment Development of a twoband enhanced vegetation index without a blue band," Remote Sens. Environ., vol. 112, pp. 3833-3845, 2008.

[6] A. Kallel, S. Le Hégarat-mascle, C. Ottlé, and L. Hubert-moy, "Determination of vegetation cover fraction by inversion of a four-parameter model based on isoline parametrization," Remote Sens. Environ., vol. 111, pp. 553-566, 2007.

[7] J. Rouse, J. W., R. H. Hass, J. A. Schell, and D. W. Deering, "Monitoring vegetation systems in the great plains with ERTS," Third ERTS Symp., pp. 309-317, 1973.

[8] G. S. Birth and G. R. McVey, "Measuring colour of growing turf with a reflectance spectrophotometer," Agron. J., vol. 60, pp. 640-649, 1968.

[9] C. Buschmann and E. Nagel, "In vivo spectroscopy and internal optics of leaves as basis for remote sensing of vegetation,” Int. J. Remote Sens., vol. 14, pp. 711-722, 1993.

[10] R. P. Sripada, R. W. Heiniger, J. . White, and A. . Meijer, "Aerial colour infrared photography for determining early in-season nitrogen requirements in corn,” Agron. J., vol. 98, no. 968-977, 2006.

[11] A. Abdollahnejad, D. Panagiotidis, and P. Surový, "Forest canopy density assessment using different approaches - Review,” J. For. Sci., vol. 63, no. 3, pp. 107-116, 2017.

[12] Ts. Purevdorj, R. Tateishi, T. Ishiyama, and Y. Honda, "Relationships between percent vegetation cover and vegetation indices," Int. J. Remote Sens., no. September 2012, pp. 37-41, 2010.

[13] J. E. Herrick, M. Mattocks, D. Toledo, and J. Van Zee, "Comparison of three vegetation monitoring methods : Their relative utility for ecological assessment and monitoring," vol. 9, pp. 1001-1008, 2009.

[14] V. Salas-aguilar and F. Rojas-garc, "Estimation of vegetation cover using digital photography in a regional survey of Central Mexico," pp. 1-18, 2017.

[15] H. Liu, L. Zheng, and S. Yin, "Multi-perspective analysis of vegetation cover changes and driving factors of long time series based on climate and terrain data in Hanjiang River Basin , China," 2018.

PT X, "Laporan Pelaksanaan Reklamasi Tahun 2019," Batulicin, Kalimantan Selatan, 2019.

S. Barati, B. Rayegani, M. Saati, A. Sharifi, and M. Nasri, "Comparison the accuracies of different spectral indices for estimation of vegetation cover fraction in sparse vegetated areas," Egypt. J. Remote Sens. Sp. Sci., vol. 14, no. 1, pp. 49-56, 2011. 